\title{
Comparison of antibiotic resistant Escherichia coli obtained from drinking water sources in northern Tanzania: a cross-sectional study
}

\author{
Beatus Lyimo ${ }^{1 *}$, Joram Buza ${ }^{1}$, Murugan Subbiah², Woutrina Smith ${ }^{3}$ and Douglas R. Call ${ }^{1,2}$
}

\begin{abstract}
Background: Antimicrobial resistance (AMR) is a growing and significant threat to public health on a global scale. Escherichia coli comprises Gram-negative, fecal-borne pathogenic and commensal bacteria that are frequently associated with antibiotic resistance. AMR E. coli can be ingested via food, water and direct contact with fecal contamination.

Methods: We estimated the prevalence of AMR Escherichia coli from select drinking water sources in northern Tanzania. Water samples $(n=155)$ were collected and plated onto Hi-Crome E. coli and MacConkey agar.

Presumptive E. coli were confirmed by using a uidA PCR assay. Antibiotic susceptibility breakpoint assays were used to determine the resistance patterns of each isolate for 10 antibiotics. Isolates were also characterized by select PCR genotyping and macro-restriction digest assays.

Results: E. coli was isolated from $71 \%$ of the water samples, and of the 1819 E. coli tested, $46.9 \%$ were resistant to one or more antibiotics. Resistance to ampicillin, streptomycin, sulfamethoxazole, tetracycline, and trimethoprim was significantly higher (15-30\%) compared to other tested antibiotics $(0-6 \% ; P<0.05)$. Of the $\beta$-lactam-resistant isolates, bla $a_{\text {TEM-1 }}$ was predominant $(67 \%)$ followed by bla $a_{\mathrm{CTX}-\mathrm{M}}(17.7 \%)$ and bla $a_{\mathrm{SHV}-1}(6.0 \%)$. Among the tetracyclineresistant isolates, tet(A) was predominant (57.4\%) followed by tet(B) $(24.0 \%)$. E. coli isolates obtained from these water sources were genetically diverse with few matching macro-restriction digest patterns.

Conclusion: Water supplies in northern Tanzania may be a source of AMR E. coli for people and animals. Further studies are needed to identify the source of these contaminants and devise effective intervention strategies.
\end{abstract}

Keywords: Antibiotic resistance, Water quality, Low-income country, Tanzania

\section{Background}

Despite meeting the Millennium Development Goals for drinking water [1], 748 million mostly poor and marginalized people still lack access to quality drinking water. Of these almost a quarter (173 million) rely on untreated surface water on a daily basis and over $90 \%$ live in rural areas [1]. Fecal waste from people and animals is a major source for water pollution, particularly in lowincome countries. For instance, in 2012 approximately 1

\footnotetext{
* Correspondence: beatus.lyimo@nm-aist.ac.tz

${ }^{1}$ Nelson Mandela African Institution of Science and Technology, 447, Arusha, Tanzania

Full list of author information is available at the end of the article
}

billion people in the world did not have access to toilet facilities and instead used open and unsanitary places for defecation [1]. These communities also lack proper water supplies and depend heavily on untreated surface or shallow, unprotected water (river, ponds, and lakes) sources for consumption [2,3]. These water sources run through agricultural lands and open places and thus are frequently exposed to human and animal wastes. Consuming these contaminated water increases the risk of exposure to enteric bacterial, viral and protozoan pathogens that could cause severe diseases in people [4]. Notably, there are several strains of $E$. coli that are pathogenic to both people and animals and that can 
cause disease ranging from self-limiting diarrhea to lifethreatening hemolytic-uremic syndrome (HUS) and hemorrhagic colitis $[5,6]$.

Emergence and dissemination of antimicrobialresistant (AMR) bacteria is considered the third-largest threat to global public health in the $21^{\text {st }}$ century [7]. AMR reduces the effectiveness of antibiotic treatment and thus leads to increased morbidity, mortality, and healthcare expenditures [8]. Commensal E. coli found in people and animals is considered a potential reservoir for AMR genes [9] and these genetic traits can be transferred to E. coli or to other bacteria found in people, animals, and in the environment [10]. Presumably, water sources contaminated with AMR bacteria is one contributing factor for the higher prevalence of antibiotic resistant bacteria from people living in low-income countries [11]. For instance, studies conducted in South Africa reported a high prevalence of antibiotic resistant E. coli from both "safe" (treated and closed) and unsafe (untreated and open) water sources $[9,12]$.

Tanzania is a low-income country in East Africa that is experiencing an exponential increase of human settlements around water sources [13]. A relatively small proportion of people living in the urban and peri-urban areas have access to what are considered safe (bore-well and taps) drinking water facilities. Consumption of water containing AMR bacteria is likely to increase the risk of disseminating antibiotic resistance and pathogenic bacteria. Nevertheless, the extent of this risk, if any, has not been well described.

In this study we assessed the prevalence of antibiotic resistant E. coli from surface waters in northern Tanzania. We also characterized a panel of isolates for the presence of select antibiotic resistance genes and assessed genetic diversity by using a macro-restriction assay with pulsed-field gel electrophoresis. In the long term, understanding the degree that surface waters are contaminated will help guide intervention strategies to reduce the risk of water-borne dissemination of pathogens and the dissemination of antibiotic resistance.

\section{Methods}

\section{Study design}

The study was cross-sectional and convenience sampling was used to collect 155 water samples in select water sources in northern Tanzania between March and September 2014 (Fig. 1). Permission was sought from the local authorities before collecting water from open (rivers, lakes, streams and ponds) and closed (taps and bore-wells) water resources located in two geographically and climatically distinct areas (dry-arid; Longido, Monduli and Simanjiro districts and lush-mountainous; Moshi, Arumeru and Arusha districts; Fig. 1). Ponds (surface rain water collected in manmade reservoirs) are shallow open bodies of water that are shared between animals (livestock and wildlife) and people living in the dry-arid regions. Rivers are the primary open surface waters that are used by people and animals living in the lush-mountainous regions. The number of households that use tap and bore-well water is relatively high in lush-mountainous compared to dry-arid regions. Water samples from the ponds were collected from localities near Maasai villages while the samples from rivers were collected from low risk-, moderate risk-, and high riskstream segments of the same river in the vicinity of Arumeru (Nduruma, Tengeru) and Arusha (Temi) regions. The distance between the point where water was sampled and apparent human activities defined relative risk. If activities were observed $>300 \mathrm{~m}$ from the sample collection point this was considered a "low risk" segment while moderate and high risk corresponded to within $50-300 \mathrm{~m}$ or within $50 \mathrm{~m}$, respectively. Convenience sampling was used to collect tap water from Arusha, Arumeru, Longido, Moshi, and Monduli districts. Borewell water samples were collected from Arusha, Arumeru, Monduli, and Simanjiro (Fig. 1).

\section{Sample collection and processing for the isolation of $E$. coli} Water samples were collected in $500-\mathrm{ml}$ sterile bottles and transported in cooler boxes with ice packs to the laboratory for processing within $6 \mathrm{~h}$ (h) of collection. Water samples were analyzed using a standard membrane filtration technique with slight modification [14]. Briefly, $100 \mathrm{ml}$ of each water sample from tap and well was filtered using a $47 \mathrm{~mm}$ membrane filter (Cellulose Nitrate filter, Sartorius Stedium Biotech $\mathrm{GmbH}$, Göttingen, Germany) with a nominal pore size of $0.45 \mu \mathrm{m}$ using a vacuum filtration system. To avoid clogging of membrane pores water samples (especially turbid) from pond, river and stream were serially diluted 1:100 before filtered using the standard membrane filtration technique as above. Following filtration each filter membrane was placed on a Chromogenic selective agar plate (Hi-Crome E. coli agar, Hi Media Laboratories Prt. Ltd, Mumbai, India) [15]. The agar plates were initially incubated at $37{ }^{\circ} \mathrm{C}$ for $4 \mathrm{~h}$, followed by incubation for $16-22 \mathrm{~h}$ at $44{ }^{\circ} \mathrm{C}$. In addition, the water samples $(100 \mu \mathrm{l}$; undiluted) were directly plated onto MacConkey agar (Thermo Oxoid Remel, Lenexa, USA) using sterile glass beads and incubated overnight $(\sim 18 \mathrm{~h})$ at $37^{\circ} \mathrm{C}$.

\section{Isolation and storage of $E$. coli}

To determine the antibiotic susceptibility patterns of $E$. coli found in the water samples, up to 24 colonies/sample with morphology consistent with E. coli were picked from MacConkey agar plates using sterile toothpicks and inoculated into 96-well plates containing $150 \mu \mathrm{l}$ of Luria-Bertani broth (Difco ${ }^{\mathrm{TM}}$ LB Broth Lennox, Sparks, 


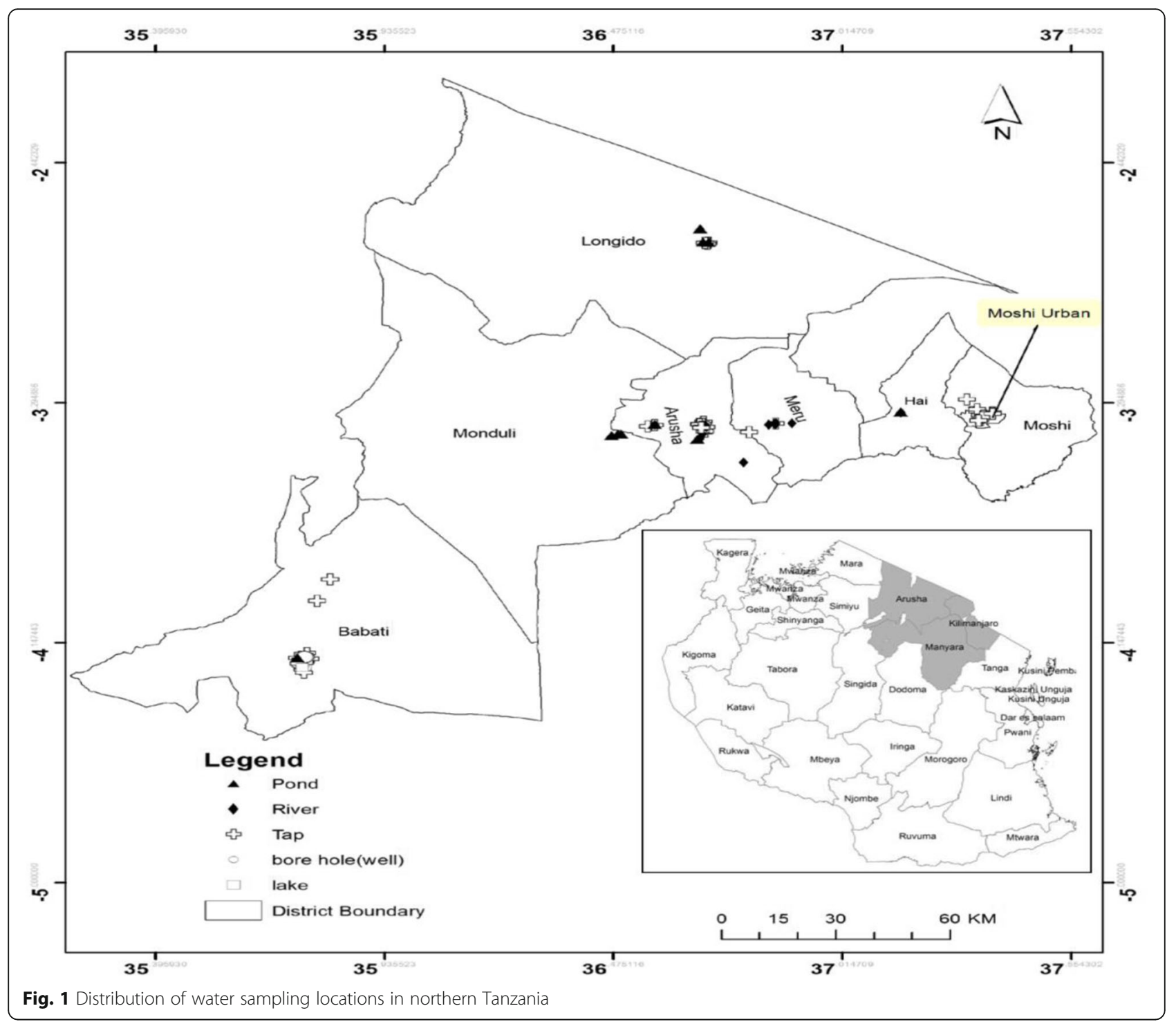

MD USA) per well. The plates were incubated overnight at $37^{\circ} \mathrm{C}$. After incubation sterile phosphate buffered glycerol was added into each well $(15 \% \mathrm{vol} / \mathrm{vol}$, final volume of glycerol) and the plates were stored at $-80{ }^{\circ} \mathrm{C}$ until shipping. For shipping, using a sterile 96-pin replicator (Boekel Scientific, Feasterville, USA), the prethawed 96-well plates containing cultures were subcultured into another 96-well plate containing $40 \mu \mathrm{l} \mathrm{LB}$ per well. These plates were incubated overnight at $37^{\circ} \mathrm{C}$. After incubation the plates were left open in a sterile incubator for drying between $32-35{ }^{\circ} \mathrm{C}$ for up to $24 \mathrm{~h}$ or until the cultures are completely desiccated. The completely desiccated plates were examined to confirm the absence of condensation and were then shipped to the Paul G. Allen School of Global Animal Health (Washington State University, Pullman, WA) for further analysis. Upon receipt $150 \mu \mathrm{l}$ of LB broth was added to the desiccated wells and incubated overnight at $37{ }^{\circ} \mathrm{C}$ to recover the isolates. All the recovered isolates were tested for the presence of uidA gene specific for $E$. coli using a PCR [16].

\section{Antibiotic susceptibility testing}

An antibiotic susceptibility breakpoint assay was used to estimate the prevalence of antibiotic-resistant E. coli from the study collection. For this assay, the following concentrations of antibiotics were used: amoxicillin/clavulanate potassium (AMC), 32/16 $\mu \mathrm{g} / \mathrm{ml}$ (MP Biomedicals, Illkirch, France and Sigma-Aldrich, St Louis, MO, respectively); ampicillin (Amp), $32 \mu \mathrm{g} / \mathrm{ml}$ (Fisher Scientific, Fair Lawn, New Jersey); ceftazidime (Cfz), $8 \mu \mathrm{g} / \mathrm{ml}$ (Sigma-Aldrich); chloramphenicol (Chl), $32 \mu \mathrm{g} / \mathrm{ml}$ (Sigma-Aldrich); ciprofloxacin (Cip), $4 \mu \mathrm{g} / \mathrm{ml}$ (LKT Laboratories, Inc., St. Paul, MN); kanamycin (Kan), $64 \mu \mathrm{g} / \mathrm{ml}$ 
(Sigma-Aldrich); streptomycin (Str), $16 \mu \mathrm{g} / \mathrm{ml}$ (Fisher Scientific); sulfamethoxazole (Sul), $512 \mu \mathrm{g} / \mathrm{ml}$ (MP Biomedicals); tetracycline (Tet), $16 \mu \mathrm{g} / \mathrm{ml}$ (GTS, San Diego, CA); and trimethoprim (Tri), $8 \mu \mathrm{g} / \mathrm{ml}$ (MP Biomedicals). Selection of antibiotic concentrations was guided by the CLSI minimum inhibitory concentrations (MIC) for Enterobacteriaceae, except for streptomycin. The streptomycin concentration was determined by estimating the MIC for a susceptible K-12 strain of $E$. coli strain.

Breakpoint assays were conducted by preparing MacConkey agar with the indicated concentration of an antibiotic (one antibiotic per $150 \mathrm{~mm}$ plate). E. coli isolates were transferred onto the antibiotic containing media using a 96-pin replicator (Boekel Scientific, Fisher Scientific) from overnight culture in LB broth. After incubation at $37{ }^{\circ} \mathrm{C}$ for $24 \mathrm{~h}$, growth was interpreted as resistant and no growth was interpreted as susceptible $[17,18]$. E. coli strains K-12 (negative control, susceptible to all antibiotics tested) and $\mathrm{H} 4 \mathrm{H}$ (positive control, E. coli strain harboring a $\sim 148 \mathrm{~kb}$ plasmid that encodes resistance to 13 antibiotics including all of the antibiotics tested [19]) were used as reference strains for antibiotic susceptibility testing. The prevalence of antibiotic resistance was estimated by dividing the number of isolates resistant to a given antibiotic with the total number of isolates.

\section{Macro-restriction digest and pulsed-field gel electro- phoresis (PFGE)}

Thirty-seven $E$. coli isolates with $>2$ antibiotic resistance phenotypes from each water source were characterized by using Xbal macro-restriction digest assays with slight modifications from the PulseNet protocol [20]. Briefly, overnight culture was adjusted to an optical density of 1.4 using a spectrophotometer $(610 \mathrm{~nm})$ and $200 \mu \mathrm{l}$ of the adjusted culture was augmented with proteinase $\mathrm{K}$ $(10 \mu \mathrm{l}$ at $20 \mathrm{mg} / \mathrm{ml})$. Melted SeaKem Gold agarose (FMC, Rockland, ME, USA) was added and gently mixed before dispensing into plug molds (Bio-Rad, Hercules, CA) for $15 \mathrm{~min}$. Plugs were incubated in ES buffer (0.5 M EDTA, pH 9.0, 1 \% sodium lauroyl sarcosine) with proteinase $\mathrm{K}$ at $54{ }^{\circ} \mathrm{C}$ for $1 \mathrm{~h}$ and then washed $3 \mathrm{X}$ for $1 \mathrm{~h}$ in $1 \mathrm{M} \mathrm{TE}$ and $0.5 \mathrm{M}$ EDTA buffer. Plugs were then treated with Xbal for $3 \mathrm{~h}$ in a water bath at $37^{\circ} \mathrm{C}$. Restriction fragments were then resolved by electrophoresis after inserting into $1 \%$ SeaKem Gold agarose gels by using a CHEF DRIII apparatus (Bio-Rad, Hercules, CA). Gels were immersed in 0.5X Tris-borate-EDTA buffer and electrophoresis included initial switching time of $2.2 \mathrm{~s}$ and a final switching time of $54.2 \mathrm{~s}, 6 \mathrm{~V}$ and $120^{\circ}$ angle. Fragments were resolved at $14{ }^{\circ} \mathrm{C}$ for $18 \mathrm{~h}$. Control strains of E. coli $\mathrm{O} 157: \mathrm{H} 7$ and Shigella were included on every gel to improve accuracy of fragment size estimates. After electrophoresis the gels were stained with ethidium bromide for $20 \mathrm{~min}$ and destained $3 \mathrm{X}$ for $20 \mathrm{~min}$ each with deionized water. Gel images were collected using ChemiDoc XRS Gel Photo Documentation System (Bio-Rad) and analyzed using BioNumerics software version 4.0 (Applied Maths, SintMartens-Latem, Belgium). Cluster analysis was used to compare isolates by using the Unweighted Pair Group Method with Averages (UPGMA) with $1 \%$ tolerance and a $0.5 \%$ optimization setting based on Dice coefficients.

\section{Determining the prevalence of beta-lactam and tetracyc- line resistant $E$. coli genotypes}

To estimate the prevalence of select antibiotic resistance genes, DNA templates of beta-lactam (Amp, AMC and $\mathrm{Cfz}$ ) and tetracycline-resistant $E$. coli isolates were prepared by pelleting $2 \mathrm{ml}$ of overnight culture at 12,000 $\times$ $g$ for $10 \mathrm{~min}$. The pellets were then re-suspended with $200 \mu \mathrm{l}$ of nanopure water and boiled for $10 \mathrm{~min}$ in a heat block. The boiled suspensions were centrifuged briefly and $2 \mu \mathrm{l}$ of the supernatant was used as DNA template for PCR assays. PCR assays were used to test for betalactamase encoding gene $\left(b l a_{\mathrm{TEM}-1}, \quad b l a_{\mathrm{SHV}-1}\right.$, and $\left.b l a_{\text {СтХ-M }}\right)$ and two tetracycline resistance genes [tet $(\mathrm{A})$ and tet(B)]. A total of 143 and 364 isolates (from both open and closed water sources) were tested for $b l a_{\mathrm{TEM}-1}$, $b l a_{\mathrm{SHV}-1}$, and $b l a_{\mathrm{CTX}-\mathrm{M}}$ and two tetracycline resistance genes tet $(\mathrm{A})$ and $\operatorname{tet}(\mathrm{B})$, respectively. Positive (E. coli $\mathrm{H} 4 \mathrm{H}$ ) and negative (E. coli $\mathrm{K} 12)$ control strains were included with each set of PCR tests. Reactions were performed using a DNA thermocycler (C1000 Touch Thermal Cycler, Bio-Rad) with specific primers (Table 1).

PCR reactions were performed in a total volume of $25 \mu \mathrm{l}$ that included $2 \mu \mathrm{l}$ DNA template, $12.5 \mu \mathrm{l}$ master mix (ThemoFisher Scientific), $2 \mu \mathrm{l}$ of each primer $(10 \mu \mathrm{M})$ and $8.5 \mu \mathrm{l}$ of PCR grade water. The following PCR running conditions were used for $b l a_{\mathrm{TEM}-1}$ : initial denaturation at $95{ }^{\circ} \mathrm{C}$ for $3 \mathrm{~min}$, followed by 35 cycles of denaturation at $95{ }^{\circ} \mathrm{C}$ for $1 \mathrm{~min}$, annealing at $63{ }^{\circ} \mathrm{C}$ for $1 \mathrm{~min}$ and extension at $72{ }^{\circ} \mathrm{C}$ for $1 \mathrm{~min}$ and final extension at $72{ }^{\circ} \mathrm{C}$ for $10 \mathrm{~min}$. For $b l a_{\mathrm{SHV}-1}$ PCR the conditions included initial denaturation at $94{ }^{\circ} \mathrm{C}$ for $30 \mathrm{~s}$, followed by 32 cycles of denaturation at $94{ }^{\circ} \mathrm{C}$ for $30 \mathrm{~s}$, annealing at $54{ }^{\circ} \mathrm{C}$ for $30 \mathrm{~s}$ and extension at $72{ }^{\circ} \mathrm{C}$ for $1 \mathrm{~min}$ and a final extension at $72{ }^{\circ} \mathrm{C}$ for $10 \mathrm{~min}$. For tet(A) and tet(B) PCR the conditions included denaturation was at $95{ }^{\circ} \mathrm{C}$ for $5 \mathrm{~min}$, followed by 30 cycles of denaturation at $95{ }^{\circ} \mathrm{C}$ for $30 \mathrm{~s}, 55^{\circ} \mathrm{C}$ for $30 \mathrm{~s}$ and extension at $72{ }^{\circ} \mathrm{C}$ for $30 \mathrm{~s}$ and a final extension at $72{ }^{\circ} \mathrm{C}$ for $2 \mathrm{~min}$ $[21,22]$. For CTX-M PCR the conditions included initial denaturation at $95{ }^{\circ} \mathrm{C}$ for 2 min followed by 30 cycles of denaturation at $95{ }^{\circ} \mathrm{C}$ for $15 \mathrm{~s}$, annealing at $52{ }^{\circ} \mathrm{C}$ for $15 \mathrm{~s}$, extension at $72{ }^{\circ} \mathrm{C}$ for $30 \mathrm{~s}$ and a final extension at 
Table 1 Primers sequences used in this study

\begin{tabular}{|c|c|c|}
\hline Primer & Nucleotide sequence & Reference \\
\hline \multirow[t]{2}{*}{ uidA } & LGO_uidA F-5'-GACCCACACTTTGCCGTAAT-3' & \multirow[t]{2}{*}{ This study } \\
\hline & LGO_uidA R-5'-AGTCTGGATCGCGAAAACTG-3' & \\
\hline \multirow[t]{2}{*}{ CTX-M } & F- 5'-TTTGCGATGTGCAGTACCAGTAA-3' & \multirow[t]{2}{*}{ [22] } \\
\hline & R-5'-CGATATCGTTGGTGGTGCCATA-3' & \\
\hline \multirow{2}{*}{$\begin{array}{l}\text { CTX-M-1 } \\
\text { group }\end{array}$} & F-5'-GGT TAA AAA ATC ACT GCG TC-3' & \multirow[t]{2}{*}[22]{} \\
\hline & R-5'-TTG GTG ACG ATT TTA GCC GC-3' & \\
\hline \multirow{2}{*}{$\begin{array}{l}\text { CTX-M-2 } \\
\text { group }\end{array}$} & F- 5'-ATG ATG ACT CAG AGC ATT CG-3' & \multirow[t]{2}{*}[22]{} \\
\hline & R-5'-TGG GTT ACG ATT TTC GCC GC-3' & \\
\hline \multirow{2}{*}{$\begin{array}{l}\text { CTX-M-9, } \\
\text { Toho-2 } \\
\text { group }\end{array}$} & F-5'-ATG GTG ACA AAG AGA GTG CA-3' & \multirow[t]{2}{*}[22]{} \\
\hline & R-5'-CCC TTC GGC GAT GAT TCT C-3' & \\
\hline \multirow[t]{2}{*}{$b l a_{\mathrm{SHV}}$} & F-5'-AGGATTGACTGCCTTTITG-3' & \multirow[t]{2}{*}{ [41] } \\
\hline & R-5'-ATTTGCTGATTCGCTCG-3' & \\
\hline \multirow[t]{2}{*}{$b l a \mathrm{TEM}$} & F-5'-ATCAGCAATAAACCAGC-3' & \multirow[t]{2}{*}{ [41] } \\
\hline & R-5'-CCCCGAAGAACGTTTTC-3' & \\
\hline \multirow[t]{2}{*}{$\operatorname{tet}(\mathrm{A})$} & F-5'-GAAACCCAACATACCCCTGA-3' & \multirow[t]{2}{*}{ This study } \\
\hline & R-5'-GAAGCTGAGCGGGTTGAGAG-3' & \\
\hline \multirow[t]{2}{*}{$\operatorname{tet}(\mathrm{B})$} & F-5'-GTTCGACAAAGATCGCATTG-3' & \multirow[t]{2}{*}{ This study } \\
\hline & R-5'-TCTGTATTATCACGTGTATITITGG-3' & \\
\hline
\end{tabular}

$72{ }^{\circ} \mathrm{C}$ for $7 \mathrm{~min}$ [21]. Gel electrophoresis (1.5\% agarose) was used to analyze PCR products and a 1-kb DNA ladder (Gene ruler $1 \mathrm{~Kb}$, Life Technologies) was used as a size standard. CTX-M grouping (group 1, group 2 and group 9) [22] was evaluated for all isolates that were positive for the CTX-M marker by using bi-directional DNA sequencing of CTX-M PCR amplicons (Functional Bioscience, Madison, WI). Sequencher (ver 5.0) software was used to process DNA traces, and the sequences were then compared with the reported sequences from GeneBank by using the BLAST utility (http://blast.ncbi.nlm. nih.gov/Blast.cgi).

\section{Statistical analysis}

Descriptive statistics were used to estimate the prevalence of antibiotic resistance and a student's $t$-test was used to analyze the mean of resistant isolates and resistance genes. MANOVA was used to compare the prevalence within and between groups where $P \leq 0.05$ was considered significant (SPSS Inc., Chicago, IL, USA). Between-group statistical comparisons were adjusted for compounding error by using a Bonferroni adjustment to assess significance $[P \leq 0.05 /$ (number of tests) . CLC Main Workbench (CLC Bio Aarhus, Denmark) was used for sequence alignment.

\section{Results}

A total of 155 water samples were collected from open $(n=93)$ and closed $(n=62)$ drinking water sources in dry-arid $(n=40)$ and lush-mountainous $(n=115)$ regions of northern Tanzania (Table 2). Presumptive E. coli was detected from 110 of 155 (71 \%) water samples and $100 \%$ of 1819 tested isolates were positive for the uidA PCR marker. Between dry-arid and lush-mountainous areas, we recovered an average of 11.2 and $11.9 \mathrm{E}$. coli isolates per sample, respectively (Table 2).

\section{Prevalence of antibiotic-resistant $E$. coli}

Antibiotic susceptibility testing demonstrated that at least $46.9 \%$ (854 of 1819 ) of E. coli were resistant to one or more antibiotics. With ten antibiotics tested there was a possibility of detecting $2^{10}=1024$ different combinations of resistant phenotypes, of which we detected 104 with 99 including $>1$ resistance phenotype (Table 3, Additional file 1: Table S1). Isolates that were resistant to nine out of ten antibiotics were found in pond water from the dry-arid region (AmpAMCCfzCipChlStrSulTetTri) and one isolate that was resistant to seven antibiotics was found from a lush-mountainous tap water sample (Table 3).

The mean proportion of $E$. coli isolates resistant to ampicillin, streptomycin, sulfamethoxazole, tetracycline and trimethoprim was significantly higher (15-30\%) compared to other tested antibiotics $(0-6 \% ; P<0.05)$. Resistance to these antibiotics occurred alone or in association with other antibiotics for all of the tested waters. There was no statistical difference between the prevalence of antibiotic resistance in closed and open water sources, with the exception of the prevalence of trimethoprim resistance (Fig. 2).

Prevalence of $\beta$-lactam and tetracycline resistance genes Out of 143 Amp-resistant E. coli isolates, there was no significant difference in the distribution between open and closed water isolates for $b l a_{\mathrm{TEM}-1}, b l a_{\mathrm{CTX}-\mathrm{M}}$ and bla $a_{\mathrm{SHV}-1}$ (Kruskal-Wallis test, $P>0.05$ ) (Fig. 3). Among the 16 isolates positive for $b l a_{\mathrm{CTX}-\mathrm{M}}$, fifteen were $b l a_{\mathrm{CTX}}$

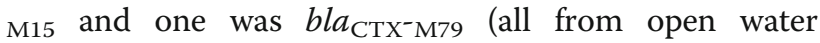
sources). Among the $\beta$-lactam-resistant isolates, bla $a_{\mathrm{TEM}}$ 1 was predominant $(67 \%)$ followed by bla ${ }_{\text {СТХ-M }}(17.7 \%)$ and $b l a_{\mathrm{SHV}-1}(6.0 \%)$. Among the 364 tetracyclineresistant $E$. coli isolates, the prevalence of tet(A) and tet(B) genotypes was equal for both open and closed water, respectively (Wilk's Lambda $=0.95, F=0.72, P=$ 0.54) (Fig. 3). Overall prevalence in tetracycline-resistant isolates, tet(A) was predominant $(57.4 \%)$ followed by tet(B) $(24.0 \%)$.

\section{Macro-restriction enzyme results}

Thirty-seven $E$. coli isolates with $>2$ antibiotic resistance phenotypes obtained from different water sources were genotyped by macro-restriction assays. A significant degree of genetic diversity was evident from these assays 
Table 2 Distribution of samples and antimicrobial resistant (AMR) E. coli in two different regions of northern Tanzania

\begin{tabular}{|c|c|c|c|c|c|c|c|}
\hline Regions & District & Source & Nature & Samples & Number of E. coli isolates & AMR E. coli & \% AMR E. coli \\
\hline \multicolumn{8}{|l|}{ Dry-arid } \\
\hline & Longido & Tap & Closed & 7 & 9 & 5 & 55 \\
\hline & Monduli & Pond & Open & 11 & 220 & 64 & 29 \\
\hline & & River & Open & 2 & 12 & 5 & 41 \\
\hline & & Tap & Closed & 8 & 44 & 30 & 68 \\
\hline & Simanjiro & Pond & Open & 6 & 83 & 21 & 25 \\
\hline & & River & Open & 2 & 36 & 11 & 30.5 \\
\hline & & Stream & Open & 1 & 1 & 1 & 100 \\
\hline & & Well & Closed & 3 & 42 & 24 & 57 \\
\hline & & Total & & 40 & 447 & 161 & \\
\hline \multicolumn{8}{|c|}{ Lush-mountainous } \\
\hline & Arumeru & River & Open & 39 & 672 & 378 & 56 \\
\hline & & Stream & Open & 1 & 26 & 25 & 96 \\
\hline & & Tap & Closed & 6 & 109 & 33 & 30 \\
\hline & & Well & Closed & 1 & 2 & 0 & 0 \\
\hline & Arusha & Pond & Open & 2 & 6 & 5 & 83 \\
\hline & & River & Open & 12 & 190 & 70 & 37 \\
\hline & & Stream & Open & 7 & 71 & 41 & 58 \\
\hline & & Tap & Closed & 15 & 196 & 91 & 46 \\
\hline & & Well & Closed & 4 & 10 & 4 & 40 \\
\hline & Moshi & Pond & Open & 3 & 4 & 1 & 25 \\
\hline & & River & Open & 4 & 10 & 2 & 20 \\
\hline & & Stream & Open & 3 & 24 & 16 & 66 \\
\hline & & Tap & Closed & 18 & 52 & 28 & 54 \\
\hline & & Total & & 115 & 1,372 & 694 & \\
\hline
\end{tabular}

Distribution of samples and antimicrobial resistant (AMR) E. coli isolated from open- and closed-water sources located in two different regions of northern Tanzania

(Fig. 4). There were a few isolates (4\%) from the same water source that clustered into one group or in adjacent clusters. For instance, isolates \#3 and \#16 (pond water isolates from Simanjiro district) were clustered in the same group, while isolates \#11, \#25 and \#13 (tap water isolates from Moshi urban area) were clustered together (Fig. 4) consistent with genetic similarity (Fig. 4).

\section{Discussion}

We assessed the presence, genetic similarity, and distribution of AMR E. coli to determine if there might be a risk of transmission to people and animals. E. coli was isolated from $71 \%$ of the water samples, and of $1819 E$. coli tested, $46.9 \%$ were resistant to one or more antibiotic. Some of the sampled waters are shared between

Table 3 Percentage of multidrug resistant E. coli isolates obtained from drinking-water sources

\begin{tabular}{|c|c|c|c|}
\hline \multirow[t]{2}{*}{ Sources (number of isolates tested) } & \multicolumn{3}{|c|}{ Number and (\%) of resistance for multiple antibiotics } \\
\hline & $2-3$ & $4-6$ & $\geq 7 P$ \\
\hline Dry-arid (447) & $38(8.5)$ & $48(10.7)$ & $10(2.2)$ \\
\hline Open sources (352) & $27(7.6)$ & $39(11.2)$ & $9(2.5) 0.199$ \\
\hline Closed sources (95) & $15(15.38)$ & $7(7.7)$ & 0 \\
\hline Lush-mountainous $(1,372)$ & $182(13.3)$ & 189 (13.8) & $23(1.7)$ \\
\hline Open sources $(1,010)$ & $147(14.6)$ & $145(14.4)$ & $9(0.9) 0.17$ \\
\hline Closed sources (362) & $38(10.6)$ & $44(12.04)$ & $15(4.2)$ \\
\hline
\end{tabular}

Antibiotics tested included ampicillin, amoxicillin/clavulanic acid, ceftazidime, ciprofloxacin, chloramphenicol, kanamycin, streptomycin, sulfamethoxazole, tetracycline, and trimethoprim 


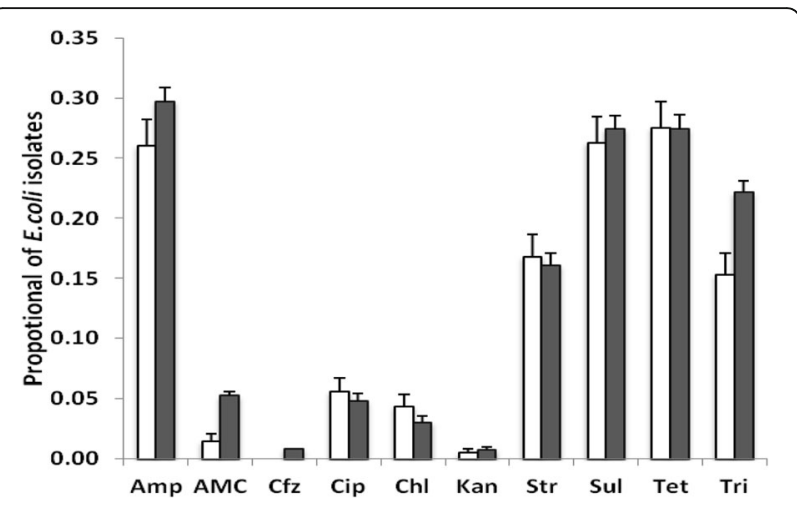

Fig. 2 Proportion of antibiotic-resistant E. coli isolates recovered from closed (white) and open (black) water sources

people and animals and can easily be contaminated with fecal bacteria. Other studies have reported the presence of antibiotic-resistant $E$. coli from surface waters. For example, Nontongana et al., [23] reported that E. coli recovered from the Kat river in South Africa were resistant to ampicillin (98\%), tetracycline (13\%) and streptomycin (8\%). Dolejská et al., [24] reported that, on average, $17 \%$ of surface water $E$. coli isolates were resistant to one or more antibiotics in the Czech Republic.

For the present study, the prevalence of resistance to ampicillin, streptomycin, sulfamethoxazole, tetracycline and trimethoprim was significantly higher than other tested antibiotics in both open and closed water sources. These five resistance phenotypes have been reported as relatively prominent for clinical isolates obtained from children $(<5$ years of age) in Tanzania [25] and this pattern of multidrug resistance has been reported elsewhere in both hospital and environmental settings [23, 26-28]. Presumably, the dissemination of these resistance traits is related to the spread of mobile genetic elements such as plasmids that are widely distributed among enteric

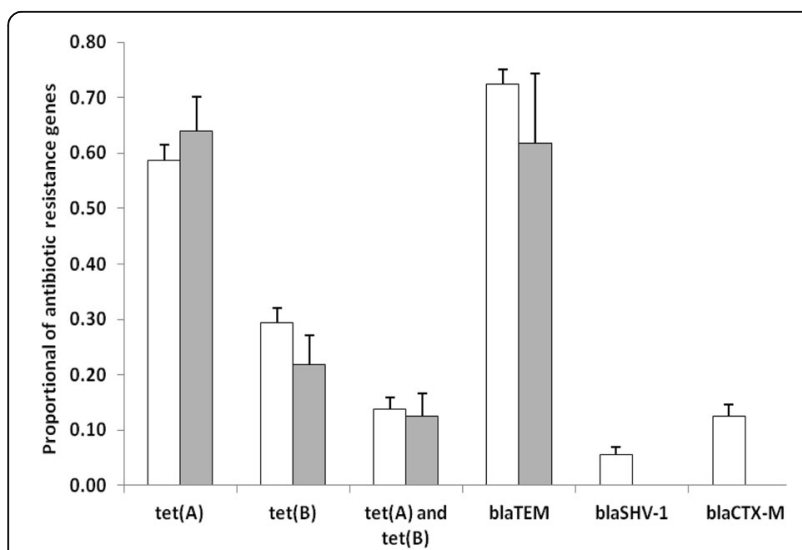

Fig. 3 Proportion of antibiotic resistance genes in open (white) and closed (black) water sources bacteria [29]. In a separate study we characterized the plasmids from a panel of 31 isolates that were isolated from our water sample survey [15]. Plasmid typing (PCR) showed that these isolates harbored at least eleven plasmid replicon types (IncI1, FIC, P, FIIA, A/C, FIB, FIA, H12, K/B B/O, and N) and the filter-mating conjugation experiments indicated that these plasmids were transmitted to the recipient hosts at a rate ranged between $10^{-1}$ and $10^{-7}$ [15].

We detected considerable genetic variation among antibiotic-resistant isolates of $E$. coli from multiple water sources, which probably should not be unexpected given the degree of genetic resolution that is afforded by macro-restriction digest assays. Nevertheless, two isolates were indistinguishable (\#3 and \#16) suggesting that clonal dissemination may contribute to the dissemination of resistant bacteria and resistance genes.

Importantly, we found isolates that are resistant to ciprofloxacin from all types of water sources, although the prevalence of ciprofloxacin-resistant E. coli (5.3\%) was less than other studies that isolated $E$. coli from sewage and treatment ponds [30]. Ciprofloxacin, like other antibiotics in Tanzania, can be purchased easily from many drug shops without a prescription. This broad-spectrum antibiotic is frequently used to treat urinary-tract infections that are also commonly resistant to the first line of antibiotics such as amoxicillin, cotrimoxazole [31]. In Tanzania, resistance to members of first and second-line antibiotics has been documented in children and pregnant women with $E$. coli infection [31]. Therefore, caution should be taken to avoid indiscriminate and inappropriate use of antibiotics especially in developing countries like Tanzania where these drugs are often sold without prescription, contrary to drug regulation [32].

We also documented a high prevalence of the bla $a_{\mathrm{TEM}}$ 1 and tet(A) genes, which is similar to reports from India and Thailand $[33,34]$. Bla $a_{\mathrm{TEM}-1}$ is widely distributed by plasmids and encodes a clinically significant, broad spectrum $\beta$-lactamase that hydrolyzes many $\beta$-lactams in addition to many penicillins. Christopher et al., [25] reported that $100 \%$ of E. coli clinical isolates from children in Tanzania were resistant to ampicillin and these may have harbored $b l a_{\text {TEM-1 }}$. The high prevalence could also be due to higher utilization of beta-lactams antibiotic classes in many areas in Tanzania [35]. Moreover tet(A), which is plasmid mediated, encodes an active efflux pump that functions against all tetracycline drugs.

We found that $E$. coli collected from both closed and open water sources harbored tet(B) resistance genes, but we only detected $b l a_{\mathrm{CTX}-\mathrm{M} 79}$ and $b l a_{\mathrm{CTX}-\mathrm{M} 15}$ genes from open water sources. Tet(B) confers resistance to the second generation of tetracycline (e.g., minocycline) [36] while $b l a_{\text {CTX-M15 }}$ exerts hydrolytic activity against ceftazidime, a third-generation cephalosporin that is frequently 


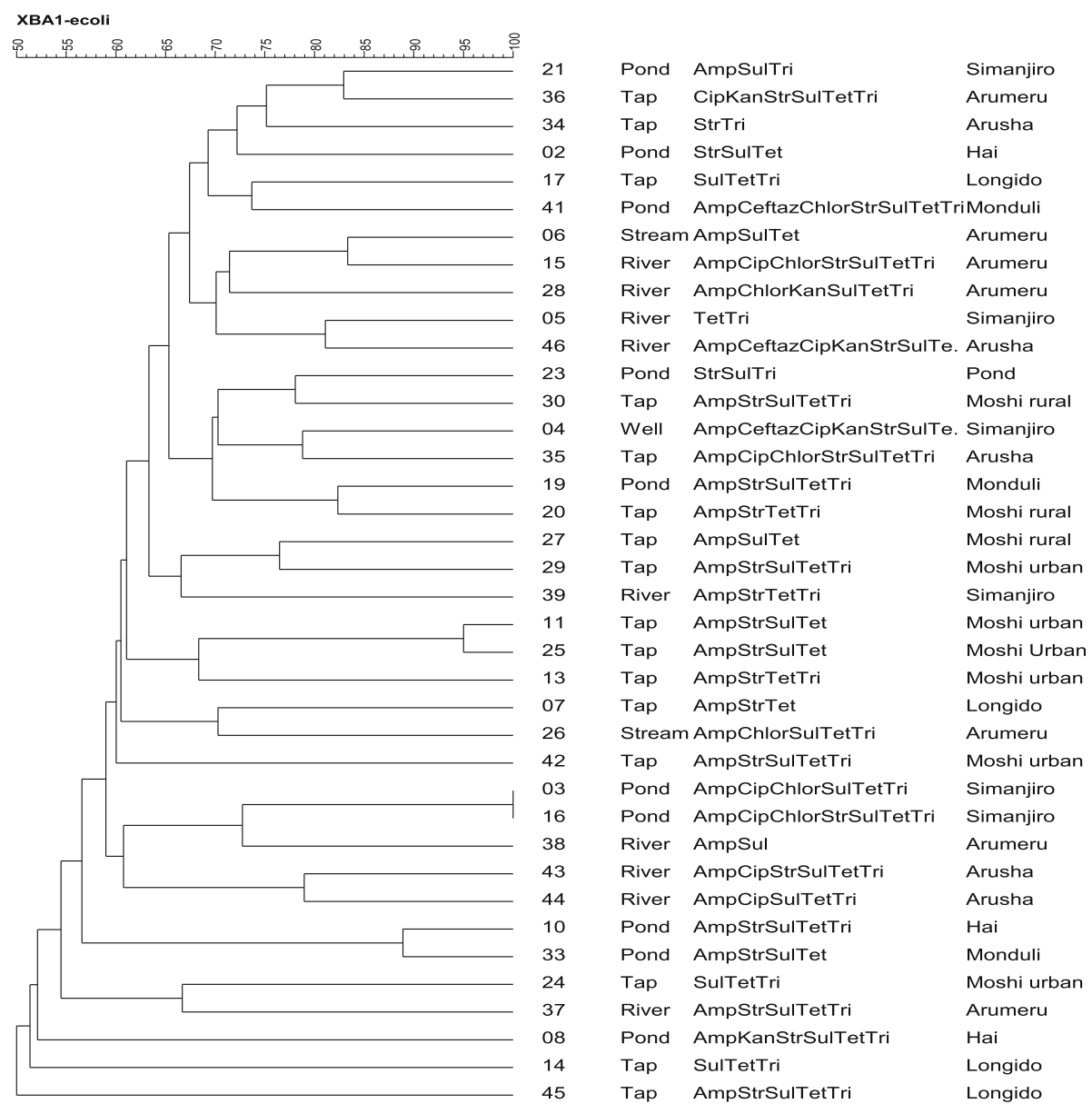

Fig. 4 Dendrogram from macro-restriction digest assays for multidrug-resistant $E$. coli isolates from different surface water

used in people [37]. The detection of bla sources in northern Tanzania is consistent with previous reports of its widespread distribution [38]. Bla $a_{\mathrm{CTX}-\mathrm{M} 79}$ has been isolated from people and farmed fish in China, and from cattle in the USA [39]. In Tanzania, we believe that this is the first report of $b l a_{\mathrm{CTX}-\mathrm{M} 79}$ from $E$. coli water isolates. Emergence and dissemination of resistant bacteria for extended-spectrum cephalosporins in drinking water should be a point of concern to physicians and health officers who manage infections in both hospital and community settings [40].

\section{Conclusion}

We report detection of a relatively high prevalence of ampicillin, tetracycline, trimethoprim, sulpamethoxazole and streptomycin resistant E. coli $(15-30 \%)$ in all sources of water commonly used by people in northern Tanzania. Because of shared-access, it is likely that livestock and people are exposed to AMR bacteria on a daily basis in communities where water treatment options are limited. Further work is needed to determine if these exposures lead to negative health outcomes.

\section{Additional file}

Additional file 1: Table S1. Resistance pattern (104 different phenotypes). (DOC $134 \mathrm{~kb})$

\section{Abbreviations}

AMR: Antimicrobial resistance; CLSI: Clinical and Laboratory Standards Institute; CTX-M: Cefotaxime- Munich; DNA: Deoxyribonucleic acid; ESBL: Extended spectrum $\beta$-lactamase; MANOVA: Multivariate Analysis of Variance; MDR: Multidrug resistance; PCR: Polymerase chain reaction; PFGE: Pulsed field gel electrophoresis; WHO: World Health Organization

\section{Acknowledgements}

Lisa Orfe, Lisa Jones, Deogratius Mshanga and Sylivester Temba provided technical assistance. Dr. Francis Shahada (deceased) helped with in the study design.

\section{Funding}

This work was funded in part by the COSTECH through the Nelson Mandela Africa Institution of Science and Technology Arusha Tanzania, the Paul G. Allen School for Global Animal Health and the National Science Foundation (DEB1216040). Additional support was provided by the Prof Woutrina Smith.

Availability of data and materials

All relevant data is reported in the manuscript. 


\section{Authors' contributions}

BL developed the study design; BL collected, processed samples; BL, SM analyzed samples; BL, SM, JB, WS and DRC prepared, read and approved the final manuscript.

\section{Competing interests}

The authors declare that they have no competing interests.

\section{Consent for publication}

All authors consent to the submitted version of this manuscript.

\section{Ethics approval and consent to participate}

No human subjects samples or data was used in this study and so no Institutional Review Board (IRB) approval or participants consent were needed.

\section{Author details}

'Nelson Mandela African Institution of Science and Technology, 447, Arusha, Tanzania. ${ }^{2}$ Paul G. Allen School for Global Animal Health, Washington State University, Pullman, WA 99164, USA. ${ }^{3}$ One Health Institute, School of Veterinary Medicine, University of California, Davis, CA 95616, USA.

\section{Received: 29 June 2016 Accepted: 26 October 2016}

Published online: 03 November 2016

\section{References}

1. WHO. Progress on drinking water and sanitation. Geneva: World Health Organization; 2014. http://www.who.int/water_sanitation_health/publications/ 2014/jmp-report/en/.

2. Jenkins M. Gross Fecal Pollution of a Rural Watershed in Kenya: Research Identifying Cattle as a Major Source in the River Njoro Watershed. Research Brief. 08-01 SUMAWA 2008. http://glcrsp.ucdavis.edu/publications/SUMAWA/ 08-01-SUMAWA pdf.

3. WHO and Unicef. WHO and Unicef, 2006. Meeting the MDG drinking water and sanitation target: the urban and rural challenge of the decade. Geneva: World Health Organization; 2006.

4. WHO. Waterborne zoonoses. Identification, causes, and control. 2004 www.who.int/water_sanitation_health/diseases/zoonoses.pdf.

5. The Center for Food Security and Public health. Enterohemorrhagic Escherichia coli infections. 2009. http://www.cfsph.iastate.edu/Factsheets/ pdfs/e_coli.pdf.

6. Orth D, Grif K, Zimmerhackl LB, Wurzner R. Prevention and treatment of enterohemorrhagic Escherichia coli infections in humans. Expert Rev Anti Infect Ther. 2008:6:101-8

7. WHO. Antimicrobial resistance: global report on surveillance. 2014. http://www.who.int/drugresistance/documents/surveillancereport/en/.

8. Roberts RR, Hota B, Ahmad I, Scott RD, Foster SD, Abbasi F, Schabowski S, Kampe LM, Ciavarella GG, Supino M, Naples J, Cordell R, Levy SB, Weinstein RA. Hospital and societal costs of antimicrobial-resistant infections in a Chicago teaching hospital: implications for antibiotic stewardship. Clin Infect Dis. 2009:49:1175-84

9. Wose Kinge CN, Ateba CN, Kawadza DT. Antibiotic resistance profiles of Escherichia coli isolated from different water sources in the Mmabatho locality, Northwest Province, South Africa. S Afr J Sci. 2010;106:44-9.

10. Balasubramaniam A, Eswaran MA, Suresh P, Sukumar K. Detection of tetracycline resistance determinant tet $\mathrm{A}$ gene and antimicrobial resistance pattern in Escherichia coli isolates recovered from healthy layer chickens. Vet World. 2014;7:635-8.

11. Okeke IN, Lamikanra A, Edelman R. Socioeconomic and behavioral factors leading to acquired bacterial resistance to antibiotics in developing countries. Emerg Infect Dis. 1999;5:18-27.

12. Dekker D, Krumkamp R, Sarpong N, Frickmann H, Boahen K, Frimpong M, Asare R, Larbi R, Hagen R, Poppert S, Rabsch W, Marks F, Adu-Sarkodie Y, May J. Drinking water from dug wells in rural Ghana - salmonella contamination, environmental factors, and genotypes. Int J Environ Res Public Health. 2015:12:3535-46.

13. Ministry of Lands and Human Settlements Development. Tanzania National Human Settlements Development Policy. 2000. http://www.tanzania.go.tz/ egov_uploads/documents/nationalhumansettlements_en.pdf.
14. EPA. Method 1604: total coliforms and Escherichia coli in water by membrane filtration using a simultaneous detection technique (Ml medium). 2002.

15. Lyimo B, Buza J, Subbiah M, Temba S, Kipasika H, Smith W, Call DR. IncF Plasmids Are Commonly Carried by Antibiotic Resistant Escherichia coli Isolated from Drinking Water Sources in Northern Tanzania. Int J Microbiol. 2016;2016:7. Article ID 3103672

16. Iqbal S, Robinson J, Deere D, Saunders JR, Edwards C, Porter J. Efficiency of the polymerase chain reaction amplification of the uid gene for detection of Escherichia coli in contaminated water. Lett Appl Microbiol. 1997:24:498-502.

17. Subbiah M, Top EM, Shah DH, Call DR. Selection pressure required for longterm persistence of blaCMY-2-positive IncA/C plasmids. Appl Environ Microbiol. 2011;77:4486-93.

18. Clinical and Laboratory Standards Institute. Performance standards for antimicrobial susceptibility testing. Approved standard. In twenty fourth edition document M100-S24. Wayne: Clinical and Laboratory Standards Institute (CLSI); 2014.

19. Call DR, Singer RS, Meng D, Broschat SL, Orfe LH, Anderson JM, Herndon DR, Kappmeyer LS, Daniels JB, Besser TE. blaCMY-2-positive IncA/C plasmids from Escherichia coli and Salmonella enterica are a distinct component of a larger lineage of plasmids. Antimicrob Agents Chemother. 2010;54:590-6.

20. CDC. Standard Operating Procedure for PulseNet PFGE of Escherichia coli O157: H7, Escherichia coli non - 0157 (STEC), Salmonella serotypes, Shigella sonnei and Shigella flexneri. 2013. 157:1-13. https://www.cdc.gov/pulsenet/ pdf/ecoli-shigella-salmonella-pfge-protocol-508c.pdf.

21. Eckert C, Gautier V, Arlet G. DNA sequence analysis of the genetic environment of various blaCTX-M genes. J Antimicrob Chemother. 2006;57:14-23.

22. Saladin M, Cao VTB, Lambert T, Donay JL, Herrmann JL, Ould-Hocine Z, Verdet C, Delisle F, Philippon A, Arlet G. Diversity of CTX-M B-lactamases and their promoter regions from Enterobacteriaceae isolated in three Parisian hospitals. FEMS Microbiol Lett. 2002;209:161-8.

23. Nontongana N, Sibanda T, Ngwenya E, Okoh Al. Prevalence and antibiogram profiling of Escherichia coli pathotypes isolated from the Kat river and the fort Beaufort abstraction water. Int J Environ Res Public Health. 2014;11:8213-27.

24. Dolejská M, Bierosová B, Kohoutová L, Literák I, Cízek A. Antibiotic-resistant Salmonella and Escherichia coli isolates with integrons and extendedspectrum beta-lactamases in surface water and sympatric black-headed gulls. J Appl Microbiol. 2009;106:1941-50.

25. Christopher A, Mshana SE, Kidenya BR, Hokororo A, Morona D. Bacteremia and resistant gram-negative pathogens among under-fives in Tanzania. Ital J Pediatr. 2013;39:27.

26. Wang C, Gu X, Zhang S, Wang P, Guo C, Gu J, Hou J. Characterization of antibiotic-resistance genes in antibiotic resistance Escherichia coli isolates from a lake. Arch Environ Contam Toxicol. 2013;65:635-41.

27. Lima AA, Lima NL, Pinho MC, Barros Junior EA, Teixeira MJ, Martins MC, Guerrant RL. High frequency of strains multiply resistant to ampicillin, trimethoprim-sulfamethoxazole, streptomycin, chloramphenicol, and tetracycline isolated from patients with shigellosis in northeastern Brazil during the period 1988 to 1993. Antimicrob Agents Chemother. 1995:39.256-9.

28. Blomberg B, Mwakagile DSM, Urassa WK, Maselle SY, Mashurano M, Digranes A, Harthug S, Langeland N. Surveillance of antimicrobial resistance at a tertiary hospital in Tanzania. BMC Public Health. 2004;4:45.

29. Berglund B. Environmental dissemination of antibiotic resistance genes and correlation to anthropogenic contamination with antibiotics. Infect Ecol Epidemiol. 2015;5:28564

30. Amaya E, Reyes D, Paniagua M, Calderón S, Rashid M-U, Colque P, Kühn I, Möllby R, Weintraub A, Nord CE. Antibiotic resistance patterns of Escherichia coli isolates from different aquatic environmental sources in León, Nicaragua. Clin Microbiol Infect. 2012;18:E347-54.

31. Global Antibiotic Resistance Partnership_Tanzania Working Group. Situation Analysis and Recommendations: Antibiotic Use and Resistance in Tanzania. Washington, DC and New Delhi: Center for Disease Dynamics, Economics \& Policy; 2015.

32. Rahman MM, Haq JA, Hossain MA, Sultana R, Islam F, et al. Prevalence of extended-spectrum beta-lactamase-producing Escherichia coli and Klebsiella pneumoniae in an urban hospital in Dhaka, Bangladesh. Int J Antimicrob Agents. 2004;24:508-10.

33. Diwan V, Chandran SP, Tamhankar a J, Stålsby Lundborg C, Macaden R. Identification of extended-spectrum $\beta$-lactamase and quinolone resistance 
genes in Escherichia coli isolated from hospital wastewater from central India. J Antimicrob Chemother. 2012;67:857-9.

34. Changkaew K, Utrarachkij F, Siripanichgon K, Nakajima C, Suthienkul O, Suzuki Y. Characterization of antibiotic resistance in Escherichia coli isolated from shrimps and their environment. J Food Prot. 2014;77:1394-401.

35. van den Boogaard J, Semvua HH, Boeree MJ, Aarnoutse RE, Kibiki GS. Sale of fluoroquinolones in northern Tanzania: a potential threat for fluoroquinolone use in tuberculosis treatment. J Antimicrob Chemother. 2009;65:145-7.

36. Vilacoba E, Almuzara M, Gulone L, Traglia GM, Figueroa S a, Sly G, Fernández A, Centrón D, Ramírez MS. Emergence and spread of plasmidborne tet(B):ISCR2 in minocycline- resistant Acinetobacter baumannii isolates. Antimicrob Agents Chemother. 2013;57:651-4.

37. Baraniak A, Fiett J, Hryniewicz W, Nordmann P, Gniadkowski M. Ceftazidimehydrolysing CTX-M-15 extended-spectrum beta-lactamase (ESBL) in Poland. J Antimicrob Chemother. 2002;50:393-6.

38. Park SH, Byun J-H, Choi S-M, Lee D-G, Kim S-H, Kwon J-C, Park C, Choi J-H, Yoo J-H. Molecular epidemiology of extended-spectrum $\beta$-lactamaseproducing Escherichia coli in the community and hospital in Korea: emergence of ST131 producing CTX-M-15. BMC Infect Dis. 2012;12:149.

39. Su Fei T, Bai Yi C, Yun Zhuo Chu SW. Prevalence of rectal carriage of extended-spectrum $\beta$-lactamase-producing Escherichia coli among elderly people in community settings in China. Can J Microbiol. 2008;54:781-5.

40. Pitout JDD, Gregson DB, Church DL, Laupland KB. Population-based laboratory surveillance for AmpC $\beta$-lactamase- producing Escherichia coli, Calgary. Emerg Infect Dis. 2007;13:443-8

41. Colom K, Pérez J, Alonso R, Fernández-Aranguiz A, Lariño E, Cisterna R. Simple and reliable multiplex PCR assay for detection of blaTEM, blaSHV and blaOXA-1 genes in Enterobacteriaceae. FEMS Microbiol Lett. 2003;223:147-51.

\section{Submit your next manuscript to BioMed Central and we will help you at every step:}

- We accept pre-submission inquiries

- Our selector tool helps you to find the most relevant journal

- We provide round the clock customer support

- Convenient online submission

- Thorough peer review

- Inclusion in PubMed and all major indexing services

- Maximum visibility for your research

Submit your manuscript at www.biomedcentral.com/submit
Biomed Central 